\title{
EDITORIAL
}

\section{Persistent Risk for HBV Associated Hepatocellular Carcinoma in spite of Sustained and Successful Viral Suppression: The Need for Drugs for HBV Cure}

\author{
Shady Guirguis ${ }^{1}$, Richard Hann ${ }^{2}$ and Hie-Won Hann ${ }^{1,2^{*}}$
}

${ }^{1}$ Division of Gastroenterology and Hepatology, Sidney Kimmel Medical College, Thomas Jefferson University Hospital, USA

${ }^{2}$ Liver Disease Prevention Center, Sidney Kimmel Medical College, Thomas Jefferson University Hospital, USA

As the years of antiviral treatment for chronic hepatitis B increase, we are witnessing persistence of the risk for hepatocellular carcinoma (HCC). Even with successful control of hepatitis $B$ virus (HBV) replication over a decade (even over 12 years), there remains the risk for $\mathrm{HCC}$ in patients with chronic hepatitis $\mathrm{B}(\mathrm{CHB})$.

Currently, $\mathrm{HCC}$ is the second most common cancer death. ${ }^{1}$ Worldwide, the majority of HCC is causatively associated with chronic HBV infection. ${ }^{2-5}$ In 2006, with their landmark 12-year prospective study, Chen and his colleagues discovered that the high baseline HBV DNA level was closely associated with the high risk for the development of $\mathrm{HCC}{ }^{6}$

Treatment with nucleos(t)ide analogues (NAs), which began with lamivudine in1998, has resulted in significant improvement in the survival of patients with $\mathrm{CHB}$ with the reduced incidence of HCC. These findings were observed with lamivudine. ${ }^{7,8}$, entecavir ${ }^{9}$ and tenofovir. $^{10}$

Nonetheless, as the duration of antiviral treatment increases, there still remains the risk for HCC in spite of undetectable HBV DNA in serum for years as reported by different investigators ${ }^{11-15}$ with the observation time of 4-5 years including ours. ${ }^{14}$ As shown in the table 1 , our experience shows the longest years of successful viral suppression before the development of HCC. The maximum treatment period before HCC was 18.7 years. The longest time of negative serum HBV DNA was 12.4 years as shown in the table below. ${ }^{14}$

6 Open Access

Citation: Guirguis S, Hann R, Hann HW. Persistent risk for HBV associated hepatocellular carcinoma in spite of sustained and successful viral suppression: The need for drugs for HBV cure. Cancer Studies. 2017; 1(1):3.

Received: September 30, 2017

Accepted: October 11, 2017

Published: October 18, 2017

Copyright: @ 20172017 Hann et al. This is an open access article distributed under the terms of the Creative Commons Attribution License, which permits unrestricted use, distribution, and reproduction in any medium, provided the original author and source are credited..

\section{Corresponding author:} Hie-Won Hann, Division of Gastroenterology and Hepatology, Thomas Jefferson University Hospital, Philadelphia, USA.

E-mail: hie-won.hann@jefferson.edu
Table 1. Development of HCC in patients with cirrhosis on long-term antiviral therapy

\begin{tabular}{|c||c|c|c|c|c|c|c||c|c|c||}
\hline $\mathbf{P t}$ & $\begin{array}{c}\text { Date } \\
\text { startTx }\end{array}$ & $\begin{array}{c}\text { Chang } \\
\text { in } \\
\text { Child } \\
\text { Class } \\
\text { On Tx }\end{array}$ & $\begin{array}{c}\text { Date } \\
\text { HCC } \\
\text { Dx }\end{array}$ & $\begin{array}{c}\text { Size } \\
\text { (cm) and } \\
\text { site of } \\
\text { HCC }\end{array}$ & $\begin{array}{c}\text { Sex \& } \\
\text { Age } \\
\text { (yr) at } \\
\text { HCC } \\
\text { Dx }\end{array}$ & $\begin{array}{c}\text { Yrs on } \\
\text { anti-HBV } \\
\text { Tx at } \\
\text { HCC DX }\end{array}$ & $\begin{array}{c}\text { Yrs with } \\
\text { HBVDNA } \\
\text { at HCC Dx }\end{array}$ & $\begin{array}{c}\text { undetectable } \\
\text { HBV DNA } \\
\text { Before HCC } \\
\text { Dx }\end{array}$ & Anti-HBV Tx & Status \\
\hline $\mathbf{3}$ & $5 / 1998$ & $\mathrm{~A} \rightarrow \mathrm{A}$ & $2 / 2008$ & $\begin{array}{c}1.8 \times 0.9 \\
\mathrm{Lt}\end{array}$ & $76 \mathrm{~F}$ & 9.8 & UD & 6.7 & LAM+TDF & alive \\
\hline $\mathbf{6}$ & $2 / 2004$ & $\mathrm{~A} \rightarrow \mathrm{A}$ & $6 / 2013$ & $\begin{array}{c}2.5 \\
\mathrm{Lt}\end{array}$ & $57 \mathrm{M}$ & 9.3 & UD & 7.7 & TDF & dead \\
\hline $\mathbf{7}$ & $2 / 1996$ & $\mathrm{~A} \rightarrow \mathrm{A}$ & $7 / 2013$ & $\begin{array}{c}1.6 \times 1.4 \\
\mathrm{Rt}\end{array}$ & $73 \mathrm{M}$ & 17.4 & UD & 9.7 & TDF & alive \\
\hline $\mathbf{9}$ & $5 / 1996$ & $\mathrm{~A} \rightarrow \mathrm{A}$ & $\begin{array}{c}10 / 201 \\
4\end{array}$ & $\begin{array}{c}3.4 \\
\mathrm{Rt}\end{array}$ & $74 \mathrm{M}$ & 18.4 & UD & 10.4 & LAM +TDF & alive \\
\hline $\mathbf{1 0}$ & $2 / 2000$ & $\mathrm{~A} \rightarrow \mathrm{A}$ & $4 / 2015$ & $\begin{array}{c}3.4 \times 3.4 \\
\mathrm{Rt}\end{array}$ & $62 \mathrm{M}$ & 15.2 & UD & 12.4 & TDF & alive \\
\hline
\end{tabular}

UD: undetectable, LAM: lamivudine, TDF: tenofovir disoproxil fumarate

Average years on antiviral therapy: Average 14 years with a median of 15.2 years (9.3-18.4 yrs)

Average years with undetectable HBV DNA: median 9.7 years $(6.7-12.4)$

This table is from Ref. 14 (Minerva Gastroenterol Dietol 2017;63:74-76)

Persistent risk for $\mathrm{HCC}$ is attributed to the inability of eradicating the HBV with the current treatment using NA's. The NA's are effective in suppressing the replication of HBV but do not eliminate the covalently closed circular DNA (cccDNA), the template for viral replication which is located inside the nucleus of the hepatocytes.

Hepatocarcinogenesis by HBV can be multifactorial and integration of HBV DNA into the host DNA is considered one of the most important mechanisms. This integration would lead to rearrangement of chromosomes, deregulation and instability of gene expression that leads to oncogenesis. ${ }^{16-18}$. 
In order to cure the HBV infection, several approaches may be needed; eradication of the cccDNA, inhibition of viral entry from the serum to the newly formed hepatocytes, $T$ cell vaccine which targets specifically HBV DNA, enhancing the host immune activity including the innate immunity with toll-like receptor agonists and suppression of viral replication. Additional approach would be an inhibition of maturation of the pregenomic mRNA in the hepatocyte nucleus and block its export to hepatocyte cytoplasm. The process would cut down the generation of HBV core particle in the cytoplasm which would significantly reduce the production of cccDNA.

While the cure for hepatitis $C$ virus infection has become possible with the direct-acting antivirals recently developed, cure for $\mathrm{HBV}$ is still far from achievement. Fortunately, multiple compounds with potential HBV cure are being identified by the scientists in the world and the massive effort for HBV eradication is in progress. ${ }^{19,20}$ We look forward to achieving our longwaited cure of HBV infection.

\section{References}

1. Ferlay J, Soerjomataram I, Dikshit R, et al. Cancer incidence and mortality worldwide: sources, methods and major patterns in GLOBOCAN 2012. Int J Cancer. 2015;136(5): E359-E386.

2. Rani M, Yang B, Nesbit R. Hepatitis B control by 2012 in the WHO Western Pacific Region: rationale and implications. Bull WHO. 2009;87: 707-713.

3. Sanyal AJ, Yoon SK, Lencioni R. The etiology of hepatocellular carcinoma and consequences for treatment. Oncologist. 2010;15(Suppl 4): 14-22.

4. Szabó E, Páska C, Kaposi PN, et al. Similarities and differences in hepatitis B and C virus induced hepatocarcinogenesis. Pathol Oncol Res. 2004;10(1): 5-11.

5. Gurtsevitch VE. Human oncogenic viruses: hepatitis B and hepatitis C viruses and their role in hepatocarcinogenesis. Biochemistry (Mosc). 2008;73(5): 504-513.

6. Chen CJ, Yang HI, Su J, et al. Risk of hepatocellular carcinoma across a biological gradient of serum hepatitis B virus DNA level. JAMA. 2006;295(1): 65-73.

7. Liaw YF, Sung JJ, Chow WC, et al. Lamivudine for patients with chronic hepatitis B and advanced liver disease. NEngl J Med. 2004;351: 1521-1531.

8. Eun JR, Lee HJ, Kim TN, et al. Risk assessment for the development of hepatocellular carcinoma: According to on-treatment viral response during long-term lamivudine therapy in hepatitis B virusrelated liver disease. J Hepatol. 2010;53(1): 118-125.

9. Hosaka T, Suzuki F, Kobayashi M, et al. Long-term entecavir treatment reduces hepatocellular carcinoma incidence in patients with hepatitis B virus infection. Hepatology. 2013;58(1): 98-107.

10. Kim WR, Loomba R, Berg T, et al. Impact of long-term tenofovir disoproxil fumarate on incidence of hepatocellular carcinoma in patients with chronic hepatitis B. Cancer. 2015;121(20): 3631-3638.

11. Papatheodoridis GV, Manolakopoulos S, Touloumi G, et al. Virological suppression does not prevent the development of hepatocellular carcinoma in HBeAg-negative chronic hepatitis B patients with cirrhosis receiving oral antiviral(s) starting with lamivudine monotherapy: results of the nationwide HEPNET. Greece cohort study. Gut. 2011;60(8):1109-1116.

12. Papatheodoridis GV, Lampertico $P$, Manolakopoulos $S$, et al. Incidence of hepatocellular carcinoma in chronic hepatitis B patients receiving nucleos(t)ide therapy: a systematic review. J Hepatol. 2010;53(2): 348-356.

13. Vlachogiannakos J, Papatheodoridis G. Hepatocellular carcinoma in chronic hepatitis B patients under antiviral therapy. World J Gastroenterol. 2013;19(47): 8822-8830.

14. Dargan A, Wong SY, Coben R, et al. Persistent risk for hepatocellular carcinoma after more than a decade of successful hepatitis B virus suppression. Minerva Gastroenterol Dietol. 2017;63(1): 74-76.

15. Ando $\mathrm{Y}$, Ishigami $\mathrm{M}$, Ishizu $\mathrm{Y}$, et al. Cumulative incidence and risk factors for the development of hepatocellular carcinoma in patients with chronic hepatitis B who achieved sustained disappearance of viremia by nucleos(t)ide analogue treatment. Hepatol Res. 2017 (in press).

16. Brechot $C$. Pathogenesis of hepatitis $B$ virus-related hepatocellular carcinoma: old and new paradigms. Gastroenterol. 2004;127(5 Suppl 1): S56-S61. 
17. Fourel G, Trepo C, Bougueleret L, et al. Frequent activation of $\mathrm{N}$-myc genes by hepadnavirus insertion in woodchuck liver tumours. Nature. 1990;347(6290): 294-298.

18. Matsubara K, Tokino T. Integration of hepatitis B virus DNA and its implications for hepatocarcinogenesis. Mol Biol Med. 1990;7(3): 243-260.

19. Wang X-Y, Chen H-S. Emerging antivirals for the treatment of hepatitis B. World J Gastroenterol. 2014;20(24): 7707-7717.

20. Zeisel MB, Lucifora J, Mason WS, et al. Towards an HBV cure: state-of-the-art and unresolved questions--report of the ANRS workshop on HBV cure. Gut. 2015;64(8): 1314-1326. 